\title{
Ecotourism Consumption Values in the Unfamiliar Market and Mediating Role of Destination Image
}

\author{
Mobeen Jamshed Khattak
}

Assistant Manager Students' Affairs, Air University Islamabad

\author{
Dr. Jamshed Khan \\ Associate Professor, Islamabad Model Postgraduate College of Commerce, \\ Islamabad \\ jktkgaju@gmail.com \\ Bashir Khan \\ PhD Scholar, Quaid-i-Azam University, Islamabad
}

\begin{abstract}
This empirical study aims to determine the dimensions of the perceived value that are considered by the market that is unfamiliar to the ecotourism in relation to ecotourism purchase intention. The study also examines the role of destination image as mediators on the relation between perceived value and ecotourism purchase intention. Data was collected through a survey by self-administered structured questionnaire. The data from 355 respondents are analyzed using descriptive statistics, confirmatory factor analyses and regression analysis. The study findings reveal that three significant predictors i.e. conditional value, emotional value and epistemic value influence ecotourism purchase intention in the unfamiliar market. The strongest influence comes from conditional value, followed by emotional value and epistemic value. Result of this study also reveals that perceived value consisting of these three dimensions significantly influences ecotourism purchase intention. Destination image partially mediate relationship between perceived value and ecotourism purchase intention. This study concludes that only three perceived values significantly affect ecotourism purchase intention in the unfamiliar market. The conceptual model of this study is grounded in the priori causal model. Inferring strong causal effect may be considered as a limitation as it is not based on mixed models method. For deep understanding of the metaphor of values, future studies can carry qualitative investigation by experimental designs or focus groups. Connivance sampling technique also put limitation on the generalization of the study. The present study add to comprehensive understanding about the perceived values that are evaluated by individuals who are unfamiliar with ecotourism. While there is extensive research both for demand and supply in the area of ecotourism, this studyprovide the perceived values considered by the potential tourists who are unfamiliar to ecotourism.
\end{abstract}

Keywords: Perceived Value, Ecotourism, Ecotourism Purchase intentions, Destination Image, Unfamiliar Market 


\section{Introduction}

Today's tourists seek exceptional and realistic experiences of their tours to various places. People like to stay in one place for a longer time to gain exposure to cultural differences, explore local traditions and landscapes, and interact with local residents (Chaminuka, Groeneveld, \&Selomane, 2012). This recent transformation trend in tourism shifted travellers' preferences to ecotourism.

The practices of ecotourism add to improve the living conditions of local people as well as boost the business of communities in the local areas. Ecotourism can be used by governments to directly support the local economy in the alleviationof poverty. Emigration of societies through their involvement in various tourism services also can encourage governments and environmental protection (World Tourism Organization, 2017). Ecotourism involves local people in tourism services that stimulates better circulation of income of the local communities; generates indigenous enterprises, promotes traditional crafts and traditional knowledge (Bajs, 2015).

Major changes have occurred in many countries in the last two decades like growing middle class, rising education level, access to information technology, public awareness, woman empowerment, work-life imbalance and rising pollution in cities. These changes have increased the trend of tourism. Using ICT technology to connect to the tourist, many starts up firms are introducing tourism destination to both local and foreign tourists. Globally there is a rise in ecotourism but very little is known about the perceived value of ecotourism by those who are not familiar to ecotourism. To protect the natural scenic beauty, cultural heritage, eradicate poverty of the local areas and promote overall economic growth there is a dire need that marketer understands factors that determine the valueof ecotourism sites, intention of the tourists to visit ecotourism sites and image about ecotourism of this untapped market. Understanding of the perceived value of ecotourism, intention to visit and image of ecotourism will enable tourism industry marketers to motivate this unfamiliar market by offering good value for the money and useful pleasure time. In order to remain competitive, it is vital for tourism industry to understand the value perception of this untapped huge market.

There is extensive research both for demand and supply in the area of ecotourism. Most of the study examines experiential learning, pro-environmental behavior (Ting \&Cheng, 2017; De, Valois, Ajzen\& Schmidt, 2015). Some of the study in this area investigated tourist's motivation, image of ecotourism, intention and revisit intention, concern about environment and ecotourism experience (Huang \& Liu, 2017), environmental identity and ecotourism attitude (Teeroovengadum, 2018; Kim \& Kim, 2018; Lee, \& Jan 2018) and sustainability (Thompson, Gillen\&Friess, 2018; Atieno, \& Njoroge, 2018). Very little research subsists to answer as to why those potential tourists who are unfamiliar to ecotourism can be engage in ecotourism. Offering good value for money to the tourists require knowledge of the value perception of ecotourism that is comparatively a less comfortable experience as compared to conventional tourism. 
However, extant literature provides very limited research investigation into value perception of those who arunfamiliar regarding ecotourism (Chiu, Lee, \& Chen, 2014; Jamrozy\&Lawonk, 2017; Hosseinalizadeh, Jabbari, \&Haghlesan, 2018). Jamrozyand Lawonk (2017) also suggested an investigation of customers' ecotourism perceived value for those who are familiar and those who are unfamiliar with ecotourism. A plethora of research in the area of tourism have adopted the approach to analyze the factors that influence post visit factors of tourists' behavior while lacking the previsit factors that determine the likely tourist'sbehavior in the future. Jamrozy and Lawonk (2017) investigated the impact of multiple dimensions of the value perception on the ecotourism intention and suggested that the aggregate of the consumption values may have a better effect than that of the independent effect of each dimension. Tourists belonging to different countries and cultures may have different value perception and attitudes toward ecotourism experiences (Seitbattalovna, 2014). Available literature on ecotourism reveals that research in this area in Pakistan is almost non-existent.

To fill these gaps in existing research, this study investigates the influence of dimensions of perceived value and total value for those tourists that are unfamiliar with ecotourism on their ecotourism intention as suggested by Jamrozy and Lawonk (2017). Positive ecotourism image can also play an important role in the relationship between perceived value and intention (Huang \& Liu, 2017), therefore this study also considers the mediating effect of ecotourism image.

Based on the value percept theory (Westbrook \& Reilly, 1983) and theory of planned behavior the present study add to comprehensive understanding about the factors that are evaluated by individuals who are unfamiliar with ecotourism at the pre-purchase stage to determine perceived value of the ecotourism destination, total value and its impact on their intention and the role of destination image.

\section{Literature Review}

It is evident from the research of Su, Bramwell and Whalley, (2018) that tourism research is about the investigation of the people and their habits who are away from their home as well as their travel habits. According to the research conducted by Aratuo and Etienne, (2019) tourism industry have a strong impact on the economic growth of the region. However the study conducted by Hardy, Vorobjovas-Pinta and Eccleston, (2018) emphasized the importance of the transfer of tourism knowledge between the academics and noted that current investigation in this area is very inefficient. Using the theoretical lenses of theory of planned behavior and the value percept theory (Westbrook \& Reilly, 1983) this research study suggest a pre-purchase decision making framework for potential ecotourists' who are unfamiliar of ecotourism . The studies like Ziadat (2015), Song, Lyu and Jiang (2016), Seow et.al., (2017) and Huang, Chang and Backman (2018) have made use of the theory of planned behaviorand predicted tourists' intention as the most important outcome variable.According to Fishbein and Ajzen (1975) intention is the power of the decision maker drive to perform a certain behavior. Generally, the concept of intention shows likely behavior in short-term future decisions (Fandos\&Flavia'n, 2006). Keeping in view the concept of intention, eco-tourism intention can be defined as the perception of the tourist that measures his or her likelihood to visit an eco- 
tourism site in short term future. Being a significant construct of tourists' behavior, most of the studies recommend intention as the relevant variable (Liu et al., 2014).

The value perceived by the tourist before visiting the destination is the only source for positive consumer behavior. Customer value in the marketing context is about what customers' want and the belief of what they get from the product and services they buy and use (Woodruff, 1997). According to the value percept theory (Westbrook \& Reilly, 1983) value is the degree to which the performance or features desired by the consumer is offered by the product or service. According to Zeithaml (1988) value can be defined as the complete valuation of the efficacy of a product or service based on perceptions. Perception of the customer about the benefit in relation to the cost paid, constitute perceived value, however, it is highly personal and varies from person to person.

McDougall and Levesque (2000) noted that customer perceived value is one of the significant determinants of customer satisfaction that in turn impact customer behavior to purchase in the future. The analysis of Pandža (2015) has shown a direct effect of perceived value on the intention and satisfaction of tourists. Likewise, Jamal, Othman, and Muhammad (2011) tested the impact of functional and experiential dimensions on customer perceived value by adopting a multidimensional approach and noted that both dimensions determine that overall perceived value of the tourists. The analysis of Pandža (2015) has shown a direct effect of perceived value on the intention and satisfaction of tourists. . Likewise Jamrozy and Lawonk (2017) make this point that out of six multidimensional constructs of perceived value (Functional, financial, emotional, social, epistemic, conditional), four value dimensions (emotional, functional, conditional and epistemic) proved to be the significant predictors of ecotourism intention while the two value dimensions (social and financial) were found statistically insignificant. However all these studies analyzedonly post purchase behavior.Lin, Sher, and Shih (2005) empirically confirmed that perceived value has a direct effect on intention when it is conceptualized as multidimensional construct.

According to Tao et al., (2010), the functional values in the ecotourism includes the speed of the tour and its punctuality, convenience for the customer, efficiency, administration, security as well as the information about the environment. Perera and Vlosky (2013) demonstrate in their research that the functional value has a considerable impact on the purchase intention of the consumer for the ecotourism. The perceived values for the tourist also include the financial values like the price of the destination, travel expenses, return on tourism expenses, etc. hence it is important for the ecotourism activities to focus on the financial value gained by the customer (Jamrozy\&Lawonk, 2017).Gallarza et al. (2013) highlighted the importance of the social value in the perceived value for the ecotourism. LikewiseHultman et al. (2015) demonstrated the influence of the social value on the purchase intention for the ecotourism. The research of Sheth et al. (1991) demonstrates the definition of the social value as "the gain acquired from acceptability in different social groups after purchasing products and services". There are several emotional values that developed the perceived value for the customer. These include security, romance, fear, comfort, excitement, fear, passion and guilt. Sheth et al. (1991) define the emotional value as 
"the gain acquired from customers' feelings or affective states after consuming products and services". The findings of the Jamrozy and Lawonk (2017)suggested that emotional value is significant predictors of ecotourism purchase intention. The perceived value of the customer to engage with the ecotourism also includes Epistemic Value. Sheth et al. (1991) define the epistemic value as "the gain acquired from products and services to arouse curiosity provide novelty or satisfy a desire for knowledge". Jamrozy and Lawonk (2017) also noted that epistemic value is significant predictors of ecotourism purchase intention. The purchase intention for the consumer is based on the conditional value in a specific situation. It is evident from the research conducted by Sheth et al. (1991) that conditional value is the situation in which the consumer decides about the purchase in new circumstances. Tourist considers the environmental protection benefits as a condition value for the ecotourism. The study of Jamrozy and Lawonk (2017) also considered condition value is apredictors of ecotourism purchase intention.It is also recommended in the study of Jamrozy and Lawonk (2017)consumption values may work collectively than independently.

Based on the arguments in the extant literature the study put forward the following hypotheses

$\mathrm{H}_{1}$ : Functional Value has significant impact on Ecotourism Purchase Intension in the unfamiliar market.

$\mathrm{H}_{2}$ : Financial Value has significant impact on Ecotourism Purchase Intension in the unfamiliar market

$\mathrm{H}_{3}$ : Social Value has a significant impact on Ecotourism Purchase Intension in the unfamiliar market.

$\mathrm{H}_{4}$ : Emotional Value has significant impact on Ecotourism Purchase Intension in the unfamiliar market.

$\mathrm{H}_{5}$ : Epistemic Value has a significant impact on Ecotourism Purchase Intension in the unfamiliar market.

$\mathrm{H}_{6}$ : Conditional Value has significant impact on Ecotourism Purchase Intension in the unfamiliar market.

$\mathrm{H}_{7}$ : Total Perceived Value has a significant impact on Ecotourism

Purchase Intention in the unfamiliar market

One of the marketing formulation strategies is positioning. Positioning comprises of all those marketing efforts that create a suitable image of the marketing offering in the minds of the target market. Pike (2002) make this point that creating positive destination images in the mind of the target tourists' market must be a part of marketing strategies for promoting tourists' product and services. The idea of the image of the tourists' destination in the tourism research arena was introduced for the first time by Gunn (1972). Gunn (1972) also suggested that the likelihood of selecting a tourists' destination will increase with the favorable image of the destination. The image of the destination can be defined as the communication of the awareness, impressions, biases, and sentiments of an individual or group of people about a particular tourists' destination (Li et al., 2010). The study of Huang and Liu (2017) set out to investigate the role of destination image between experience and revisit intention and their results proved that the impact of ecotourism experience on revisit 
intention increase tremendously when impacted by the destination image. In another study, Chew and Jahari, (2014) significantly demonstrated the role of destination image as a mediator for the perceived risk and the revisit values. The study conducted by the Akroush et al., (2016) highlighted that the destination image has a mediating role in the service quality and destination loyalty.

Many recent studies in the field of destination image research also validated destination image as an important indicator of travel decision and plays a significant role in influencing travel intention. Based on the argument in the reviewed literature the study develop following hypothesis

$\mathrm{H}_{8}$ : Destination Image mediates the relationship between Total Perceived Value and Ecotourism Purchase Intension

Based on the various relationship revealed in the extant literature the following theoretical framework is developed for testing the hypotheses.

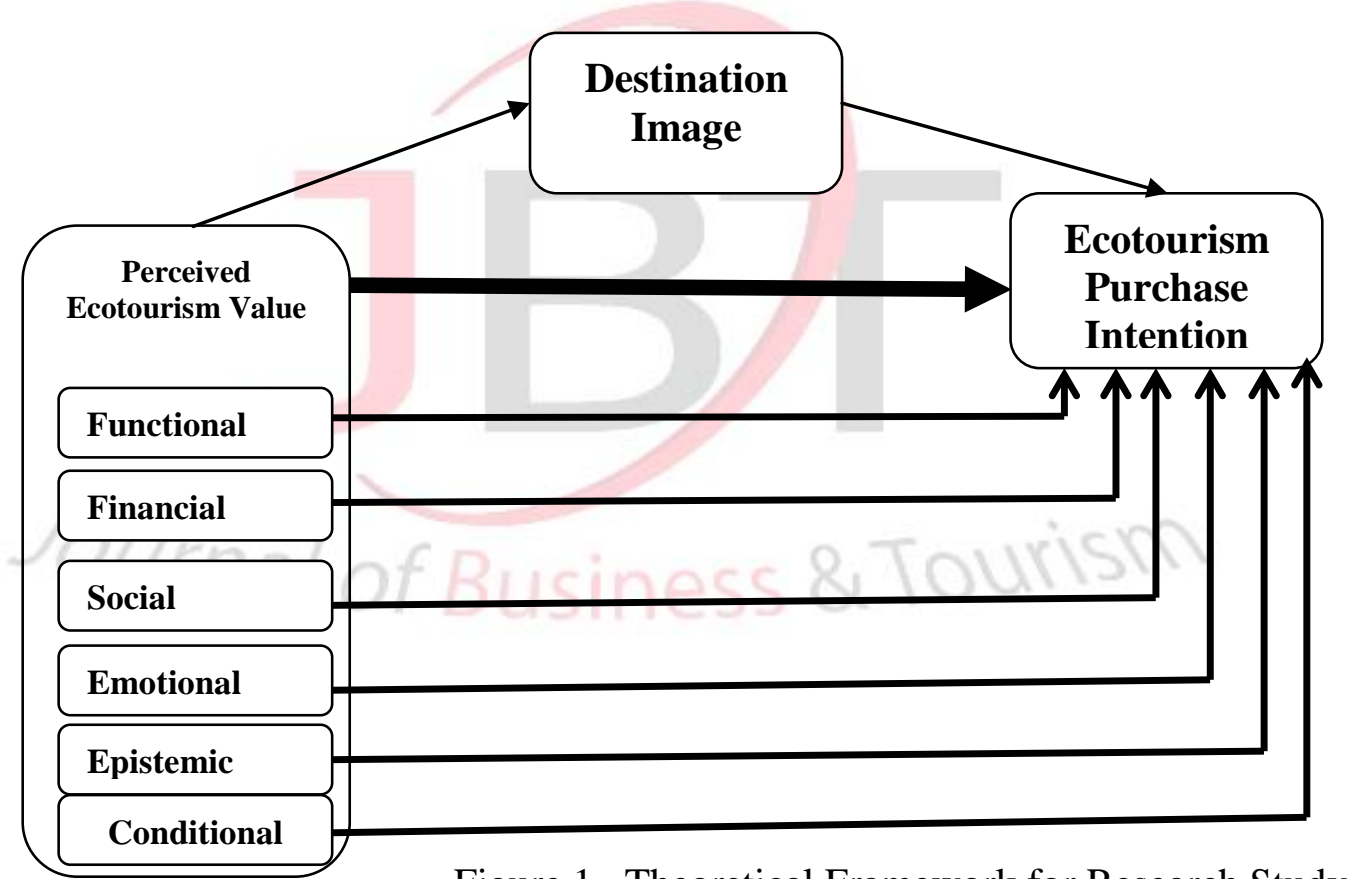

\section{Methodology}

Figure 1. Theoretical Framework for Research Study

Based on the objectives of the study the positivist philosophical approach is adopted that assumes that the knowledge of reality is gained through quantitatively verifiable results. The design of the study is based on the quantitative research methodology(Amaratunga et al., 2002). A quantitative approach of studying the social phenomenon is regarded suitable and helps in building statistical models to explain the conceptual relationship between the variables of the study that in turn render itself to the statistical tests (Bryman \& Bell, 2011). Moreover, quantitative data is considered more reliable to test the hypotheses of the study (Neill, 2007).

As the topic of the study is related with the tourism and focused on the ecotourism that is why theindividuals who tend to travel as well as willing to travel in future are a 
valuable population for the research. Moreover, contrary to the post hoc approach used in the extant literature about eco-tourism this study uses the pre-approach. In view of this fact, to achieve research objectives the tourists' population that is unfamiliar of the ecotourism is chosen for this study. The study population like Gallarza and Saura (2006) consists of university students more than 18 years of age similar to (Sanchez et al., 2006; Jamal, Othman \& Muhammad, 2011; Jamrozy and Lawonk, 2017) who are unfamiliar of ecotourism and had not previously traveled to any eco-tourist destination. The reason for selecting university students is that adolescents are always eager to discuss their tourism experience and jump at the chance to give input.

The overall population for this research is considerably large. The sampling frame for those students who are unfamiliar of ecotourism is not documented. Therefore the study makes use of non-probability convenience sampling technique as adopted by previous studies (Jamal, Othman, \& Muhammad, 2011; Teeroovengadum, 2018). Taking $95 \%$ confidence level, $50 \%$ population variability and 5\% acceptable error, the sample size for the unknown population was calculated as $n=z^{2}(p q) / e^{2}$. The sample size from the calculation is 385 (Chi \& Qu, 2008).

Data of the study was collected through a structured questionnaire and personally administered technique. To take only those units of the population in our sample who were unfamiliar of eco-tourism, an understanding, and definition of ecotourism was provided at the beginning of the questionnaire. To make sure that only those units of the population in our sample who were unfamiliar of eco-tourism, a filter question "Were you aware of eco-tourism before the introduction of ecotourism provided in this questionnaire?"was provided (Sarah \& Claire, 2013).

The questionnaire consisted of the measuring scales for each variable of the study that is adopted from the previous research studies. All items in the questionnaire are measured by taking a seven-point Likert scale (Adeleke, 2015). Ecotourism intention and multi-dimensions of the perceived value scale was adopted from Jamrozy, and Lawonk (2017). The scale of Huang and Liu (2017) was used for measuring the destination image of the respondents. All variables were measure by taking 7 points Likert scale.

In the data analysis of this research, the relationship among the variables is investigated by using the Smart PLS. The conceptual model has been developed by using Smart PLS. The simulation developed in the PLS allows the researcher to investigate the data by using several important parameters that include item loadings, validity, and reliability (Memon \& Rahman, 2014). It also estimates the strengths foe each path in the model and demonstrates the significance for each of the path (Amaro, Abrantes \& Seabra, 2016).

\section{Analyses and Results}

The sample of the study consisted of $58.6 \%$ male and $41.4 \%$ female. Statistical analysis of the study included confirmatory factor analysis, validity, reliability, descriptive analysis of items, descriptive analysis of all dimensions of perceived value, correlation analysis and normality tests. 
Using the recommended criteria of loading of each item be $>0.70$ or $>0.60$, SmartPLS software was applied to generate factor loading. The results of CFA loading and AVE indicated that the results of few items of the study variables are not up to satisfactory level. To make improvement in the results same SmartPLS procedure was adopted after deleting items with loading value of $<0.60$.

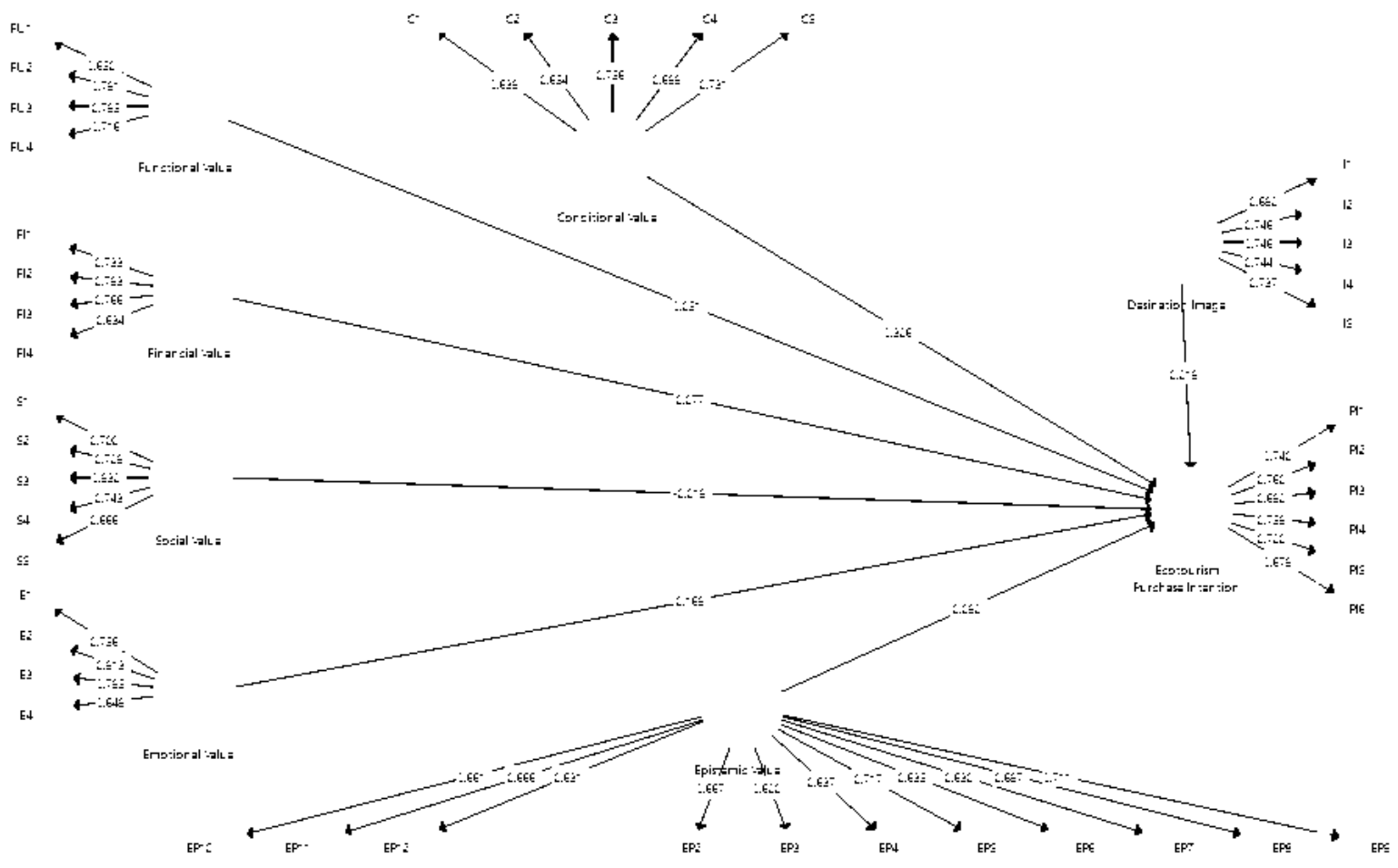

Figure 2. Results of CFA using SmartPLS after deleting items

The results in Table 1 show the value of Cronbach's Aplha, Composite Reliability and Average Variance Extration (AVE). Cronbach's Alpha, Composite Reliability values $>0.70$ are acceptable by SmartPLS, in our study all variables are within acceptable range. The values of Composite Reliability, Cronbach's Alpha are within accepted range. However AVE values of conditional value and epistemic value are $<0.50$ while the value of AVE $>0.50$. However according to Fornell and Larcker (1981) if AVE is less than 0.5, but composite reliability is higher than 0.6, the convergent validity of the construct is still adequate to measure any concept. The result in Table 1 shows that AVE values of conditional value and epistemic value are $<0.50$ but remaining indicators are within acceptable range. 
Table 1.Construct Reliability and Validity

\begin{tabular}{|c|c|c|c|c|c|}
\hline Variable & $\begin{array}{l}\text { Cronbach' } \\
\text { s Alpha }\end{array}$ & $\begin{array}{l}\text { No of } \\
\text { Items }\end{array}$ & $\begin{array}{l}\text { No of } \\
\text { Items } \\
\text { deleted }\end{array}$ & $\begin{array}{l}\text { Compo } \\
\text { site } \\
\text { Reliabi } \\
\text { lity }\end{array}$ & $\begin{array}{l}\text { Average } \\
\text { Variance } \\
\text { Extracted } \\
\text { (AVE) }\end{array}$ \\
\hline Conditional Value & 0.738 & 4 & 1 & 0.825 & 0.486 \\
\hline Destination Image & 0.786 & 4 & 0 & 0.852 & 0.535 \\
\hline $\begin{array}{l}\text { Ecotourism Purchase } \\
\text { Intention }\end{array}$ & 0.820 & 5 & 0 & 0.869 & 0.526 \\
\hline Emotional Value & 0.747 & 4 & 2 & 0.841 & 0.571 \\
\hline Epistemic Value & 0.871 & 11 & 3 & 0.895 & 0.437 \\
\hline Financial Value & 0.714 & 5 & 0 & 0.823 & 0.539 \\
\hline Functional Value & 0.713 & 6 & & 0.824 & 0.540 \\
\hline Social Value & 0.787 & 5 & & 0.854 & 0.542 \\
\hline
\end{tabular}

The results of discriminant validity of each dimension as shown in Table 2 also fall within the acceptable range in the second round of analysis.For acceptable discriminant validity the value of individual dimension should be greater than all other dimensions. All results fall in the acceptable range, as the figures in bold (square root of AVE) were all greater than the correlation with other constructs.

Table 2.Discriminant Validity

\begin{tabular}{lllllllll}
\hline Variable & $\mathbf{1}$ & $\mathbf{2}$ & $\mathbf{3}$ & $\mathbf{4}$ & $\mathbf{5}$ & $\mathbf{6}$ & $\mathbf{7}$ & $\mathbf{8}$ \\
\hline Conditional Value & $\mathbf{0 . 6 9 7}$ & & & & & & & \\
Destination Image & 0.465 & $\mathbf{0 . 7 3 1}$ & & & & & & \\
Ecotourism Purchase Intention & 0.595 & 0.528 & $\mathbf{0 . 7 2 5}$ & & & & & \\
Emotional Value & 0.457 & 0.418 & 0.496 & $\mathbf{0 . 7 5 6}$ & & & & \\
Epistemic Value & 0.554 & 0.574 & 0.515 & 0.504 & $\mathbf{0 . 6 6 1}$ & & & \\
Financial Value & 0.405 & 0.362 & 0.410 & 0.434 & 0.410 & $\mathbf{0 . 7 3 4}$ & & \\
Functional Value & 0.448 & 0.437 & 0.429 & 0.443 & 0.412 & 0.484 & $\mathbf{0 . 7 3 5}$ & \\
Social Value & 0.521 & 0.528 & 0.477 & 0.560 & 0.549 & 0.538 & 0.552 & $\mathbf{0 . 7 3 6}$ \\
\hline
\end{tabular}

Normality of the data was checked through descriptive statistics and normality test (Sekaran, 2003). The results revealed that data is normally distributed, as the descriptive statistics of all items fall within acceptable range i.e. skewness value less than $+/-2$ or equal to 2 and kurtosis less than $+/-3$ or equal to 3 (Newsom, 2005).

Mean score for respondents opinion about each perceived value dimension (Functional Value $=5.61$, Financial Value $=5.17$, Social Value $=5.34$, Emotional Value $=5.37$, Epistemic Value $=5.33$, Conditional Value $=5.46$ and Perceived Ecotourism Value $=5.39$ ) was greater than the neutral point $(>4)$, showing that respondents considered all the value dimensions important for making decision to visit an eco-tourism place. Mean value of 5.35 for ecotourism buying intention on the 
Likert scale of 1 to 7 indicated that respondents had positive intention towards ecotourism and it is most likely that they will purchase ecotourism package in the near future. Destination Image in the mind of the consumer (5.64) also showed that they have a pleasant image about ecotourism in their mind.

Results of the Pearson correlations indicated that all predictor variables (Functional Value, Financial Value, Social Value, Emotional Value, Epistemic Value, Conditional Value, Destination Image and Total Perceived Value) had a significant $(p<.01)$ zeroorder correlation with dependent variable (Ecotourism Purchase Intention).

\section{Model 1:Impact of Percieved Value Dimensions on Ecotourism Purchase Intention}

Smart PLS software was used to test the conceptual model of the study. The conceptual model was split into two parts. in first each the impact of each dependent variable was analyzed with dependent variable and then mediating variable was used to

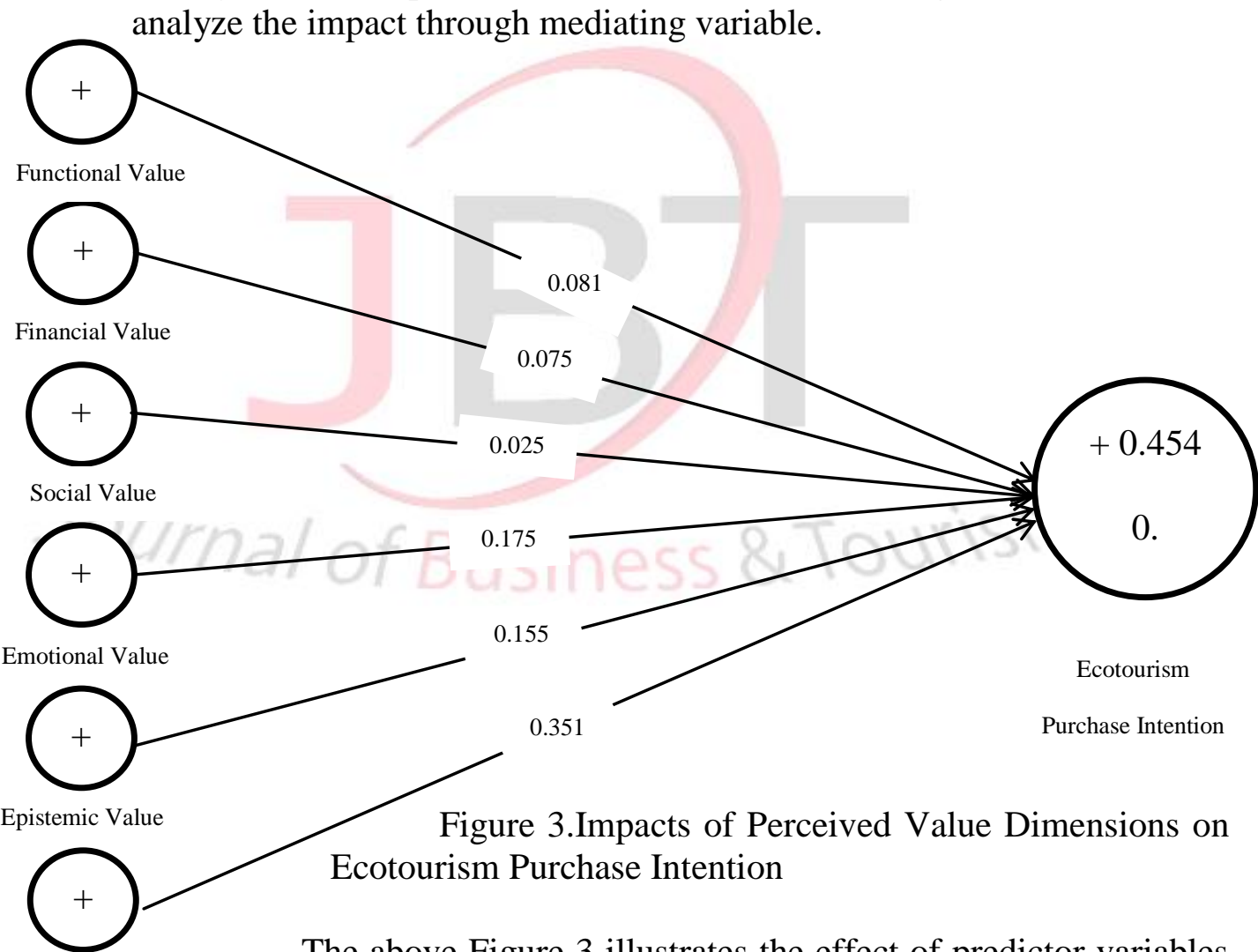

Conditional Value

The above Figure 3 illustrates the effect of predictor variables (Functional, Financial, Social, Emotional, Epistemic and Conditional Value) on Outcome variable (Ecotourism Purchase Intension). The result in Table 3 show that functional value has positive insignificant effect on Ecotourism Purchase Intension $(\beta=0.075, p=0.133)$, Functional Value and Social Value also shows insignificant impact on Ecotourism Purchase Intension $(\beta=0.081, \beta=0.025, p$ $=0.113, p=0.707$ respectively). Conditional Value has positive and significant impact on Ecotourism Purchase Intension $(\beta=0.351, p=0.000)$. Emotional Value has positive and significant impact on Ecotourism Purchase Intension $(\beta=0.175, p=$ 0007) and Epistemic Value also has positive and significant impact on Ecotourism 
Purchase Intension $(\beta=0.155, p=0.014)$. The results show that out six dimensions of perceived value, only three dimensions (Conditional, Emotional, Epistemic Value) have positive and significant impact on Ecotourism Purchase Intension, however remaining three variables (Functional, Financial and Social Value) have insignificant impact on Ecotourism Purchase Intension.

\section{Table 3.Path Coefficient for Model 1}

\begin{tabular}{llllll}
\hline & $\begin{array}{l}\text { Unstandardize } \\
\text { d Beta }\end{array}$ & $\begin{array}{l}\text { Standardize } \\
\text { d Beta }\end{array}$ & $\begin{array}{l}\text { Standar } \\
\text { d Errors }\end{array}$ & $\begin{array}{l}\text { T } \\
\text { Statistic } \\
\text { s }\end{array}$ & P Values \\
\hline Conditional Value & 0.351 & 0.346 & 064 & 5.455 & 0.000 \\
Emotional Value & 0.175 & 0.176 & 0.065 & 2.714 & 0.007 \\
Epistemic Value & 0.155 & 0.164 & 0.063 & 2.476 & 0.014 \\
Financial Value & 0.075 & 0.079 & 0.050 & 1.506 & 0.133 \\
Functional Value & 0.081 & 0.083 & 0.051 & 1.588 & 0.113 \\
Social Value & 0.025 & 0.023 & 0.066 & 0.376 & 0.707 \\
& & & & R & R Square \\
& & & & Square & Adjusted \\
Ecotourism & & & & & \\
Purchase & & & & & \\
Intention & & & & & \\
\hline
\end{tabular}

Dependent Variable: Ecotourism Purchase Intention

The Above Table 3 also show the $\mathrm{R}$ square and adjusted $\mathrm{R}$ square of the model. According to Cohen et al. (2014) for a good model, the value of $\mathrm{R}$ square of endogenous latent variable should be more than 0.26 . Since $R$ square value for the developed model is 0.454 and adjusted $\mathrm{R}$ square is 0.444 which are higher than the suggested value, the model is considered to have substantial degree of explained variance of the three dimensions of perceived value.

Results in Table 3 showed that conditional, emotional and epistemic value had significant positive regression weights, indicating university students' with higher scores on these scales had higher Ecotourism Buying Intention. Magnitude of $t$ statistics revealed that university students' Conditional Value had more impact on Ecotourism Buying Intention, followed by Emotional Control and Epistemic Value.

Results in Table 5 provided support for hypotheses $\mathrm{H}_{4}, \mathrm{H}_{5}$ and $\mathrm{H}_{6}$ but did not supported $\mathrm{H}_{1}, \mathrm{H}_{2}$ and $\mathrm{H}_{3}$. Results are consistent with the Theory of Planned Behavior (Ajzen, 1991) which states that the possibility of a behavior intention is a function of the individual's evaluation of the value of that behavior. The findings are in line with theory of planned behavior(Ajzen, 1991) and the value percept theory (Westbrook \& Reilly, 1983).

On the basis of above results we can conclude that Perceived Ecotourism Value for the unfamiliar market consists of Conditional Value, Emotional Control and Epistemic Value. Based on this fact direct and indirect impact of Perceived Ecotourism Value on Ecotourism Purchase Intention was measured by considering these three variables. 
Model 2:Impact of Percieved Ecotourism Value on Ecotourism Purchase Intention

Figure

Model

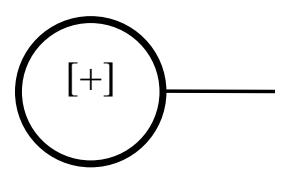

Perceived Ecotourism Value
0.642

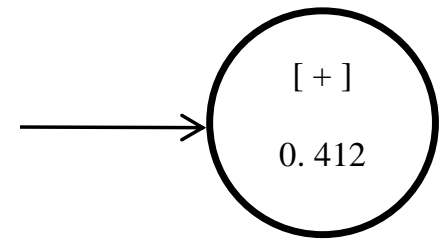

Ecotourism

4.Direct Relationship for 2

Purchase Intention

The above Figure 4, illustrate the effect of exogenous variable (Perceived Ecotourism Value) on endogenous variable (Ecotourism Purchase Intension). Results in Table 4show that perceived ecotourism value has positive and significant effect on Ecotourism Purchase Intension $(\beta=0.642, p=0.000)$.

Table 4.Path Coefficient for Model 2

\begin{tabular}{llllll}
\hline & $\begin{array}{l}\text { Unstandardi } \\
\text { zed Beta }\end{array}$ & $\begin{array}{l}\text { Standardi } \\
\text { zed Beta }\end{array}$ & $\begin{array}{l}\text { Standar } \\
\text { d } \\
\text { Errors }\end{array}$ & $\begin{array}{l}\text { T } \\
\text { Statistic } \\
\text { S }\end{array}$ & $\begin{array}{l}\text { Values } \\
\text { Perceived Ecotourism }\end{array}$ \\
$\begin{array}{llllll}\text { Value } & 0.642 & 0.650 & 0.031 & 20.914 & 0.00 \\
& \text { R Square } & \begin{array}{l}\text { R Square } \\
\text { Adjusted }\end{array} & & & \\
\text { Perceived Ecotourism } \\
\text { Value }\end{array}$ & 0.412 & 0.410 & & & \\
\hline
\end{tabular}

Dependent Variable: Ecotourism Purchase Intention

Table 4 also show R square and adjusted R square of the models. R square value for the developed model is 0.412 and adjusted $\mathrm{R}$ square value is 0.410 which are higher than the suggested value, the model is considered to have substantial degree of explained variance.

Results in Table 4 provided support for hypothesis $\mathrm{H}_{7}$. Results are consistent with the Theory of Planned Behavior (Ajzen, 1991) which states that the possibility of a behavior intention is a function of the individual's evaluation of the value of that behavior. 


\section{Model 3: Indirect Impact}

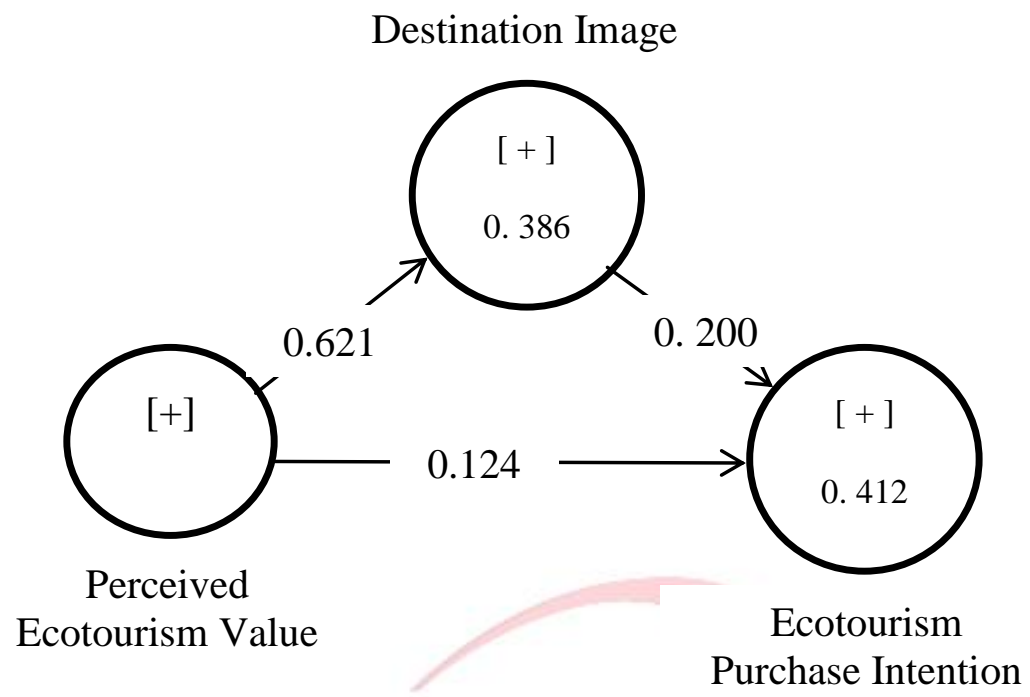

Figure 5.Indirect Effect of Destination Image

The results in Table 5 show that perceived ecotourism value has significant impact on destination image ( $\beta=0621, p=0.000)$, destination image also has significant impact on ecotourism purchase intension $(\beta=0.200, p=0.003)$, whereas perceived ecotourism value has direct impact in the presence of destination image has significant impact on ecotourism purchase intension $(\beta=0.504, p=0.000)$. The direct impact of perceived ecotourism value on ecotourism purchase intension is $(\beta=0.642$, $p=0.000$ ), hence results shows that the impact of total perceived value in the presence of destination image decreased from $\beta=0.642$ to $\beta=0.124$ on ecotourism purchase intension. So, it can beconclude that our finding supports partial mediation of destination image between perceived ecotourism value and ecotourism purchase intension and thus support hypothesis $\mathrm{H}_{8}$.

Table 5. Path Coefficient for Model 3

\begin{tabular}{lllllll}
\hline & & $\begin{array}{l}\text { Unstand } \\
\text { ardized } \\
\text { Beta }\end{array}$ & $\begin{array}{l}\text { Standa } \\
\text { rdized } \\
\text { Beta }\end{array}$ & $\begin{array}{l}\text { Standard } \\
\text { Errors }\end{array}$ & T Statistics & $\begin{array}{l}\text { P } \\
\text { Values }\end{array}$ \\
\hline $\begin{array}{l}\text { Destination } \\
>\text { Ecotourism }\end{array}$ & $\begin{array}{c}\text { Image - } \\
\text { Purchase }\end{array}$ & 0.200 & 0.199 & 0.067 & 2.963 & $\mathbf{0 . 0 0 3}$ \\
$\begin{array}{l}\text { Intention } \\
\text { Perceived }\end{array}$ & Ecotourism & & & & & \\
$\begin{array}{l}\text { Value -> } \\
\text { Destination }\end{array}$ & 0.621 & 0.626 & 0.034 & 18.435 & $\mathbf{0 . 0 0 0}$ \\
$\begin{array}{l}\text { Perceived } \\
\text { Value } \\
\text { Purchase Intention }\end{array}$ & & & & & \\
\hline Ecotourism & 0.642 & 0.650 & 0.031 & 20.914 & 0.000 \\
\hline
\end{tabular}




\section{Specific Indirect Effect}

The results in Table 6 below show that destination image is significant variable between perceived ecotourism value and ecotourism purchase intension in our study.

Table 6. Specific Indirect Effect

\begin{tabular}{|c|c|c|c|c|c|}
\hline & $\begin{array}{l}\text { Unstandardi } \\
\text { zed Beta }\end{array}$ & $\begin{array}{l}\text { Standardiz } \\
\text { ed Beta }\end{array}$ & $\begin{array}{l}\text { Standa } \\
\text { rd } \\
\text { Errors }\end{array}$ & $\begin{array}{l}\text { T } \\
\text { Statis } \\
\text { tics }\end{array}$ & $\begin{array}{l}\mathbf{P} \\
\text { Value } \\
\mathbf{S}\end{array}$ \\
\hline Ecotourism & 0.124 & 0.125 & 0.043 & 2.860 & 0.004 \\
\hline \multicolumn{6}{|l|}{ Value $->$ Destination Image } \\
\hline ->Ecotourism & & & & & \\
\hline Intention & & & & & \\
\hline
\end{tabular}

\section{Discussion}

The purpose of this study was to examine perceived ecotourism value and ecotourism purchase intention in the unfamiliar market based on the value percept theory (Westbrook \& Reilly, 1983), consumption values model (Shethet al., 1991) and theory of planned behavior that had been used in the extant literature (Jamrozy\&Lawonk, 2017). Most of the available literature on ecotourism remain focused on experiential learning, pro-environmental behavior (Ting \& Cheng, 2017; De, Valois, Ajzen\& Schmidt, 2015) and post purchase value perception of the customer regarding ecotourism (Chiu, Lee, \& Chen, 2014; Jamrozy, \&Lawonk, 2017; Hosseinalizadeh, Jabbari, \&Haghlesan, 2018; Jamrozy, \&Lawonk, 2017) of the familiar market.

The present study found significant positive impact of Conditional, Emotional, Epistemic Value on Ecotourism Purchase Intension of the unfamiliar market. The findings of the study suggest that tourism policy makers and ecotourism marketers need to focus on Conditional, Emotional, and Epistemic Value of Ecotourism while creating awareness in the unfamiliar market and motivating the unfamiliar market to purchase ecotourism trips. Previous research acknowledges the essential role of the epistemic value (Baum, 2007) and Emotional value (Jamrozy\&Lawonk, 2017) in the value creation for ecotourism. Results are also in line with the suggestion of the Jamrozy andLawonk (2017). The total value of these three factors also significantly determines ecotourism purchase intention and again is in line with the suggestion of the Jamrozy andLawonk (2017).

Results of the present study indicated that Functional, Financial and Social Value have insignificant impact on Ecotourism Purchase Intension. Presumably these perceived value aspect are mostly related to repurchase intention. The results hold true in the context of the unfamiliar market as evaluation of these aspect that could possibly be only carried out after experiencing an ecotourism trip. The result with respect to the social value is also consistent with the findings of Jamrozy andLawonk (2017).The present study also considered the role of destination image in the relationship between perceived value and intention (Huang \& Liu, 2017). Results of the study revealed significant partial mediation effect of destination image between perceived value and ecotourism purchase intention in the unfamiliar market. Therefore findings also suggest that tourism policy makers and ecotourism marketers required working on destination image building in the unfamiliar market. 


\section{Limitations and Future Research}

Though most of the hypotheses in this study have got significant support however results of the study can be generalized but with few exceptions. As the meanings and interpretation of concepts varies from culture to culture therefore care must be exercised in generalizing results. It is suggested that the significant contribution can be made by testing the conceptual model of this research in cross-cultural context.

The conceptual model of this study is grounded in the priori causal model. Inferring strong causal effect may be considered as a limitation as it is not based on mixed models method. For deep understanding of the metaphor of values, future studies can carry qualitative investigation by experimental designs or focus groups.

Connivance sampling technique also put limitation on the generalization of the study. It is suggested that future study should consider random sample. Future study can also consider ecotourism intention of those who have experienced conventional tourism trips.

\section{Conclusions and Implications}

Based on the findings of the study, a key conclusion from this empirical research is that all perceived values are not considered as value of the ecotourism trip in the unfamiliar market. Results of the study revealed that value perception of the unfamiliar market is different than the familiar market. The perceived values that significantly predicted ecotourism purchase intention in the unfamiliar market are Conditional, Emotional, and Epistemic Value. A second conclusion form this study is that total perceived value of ecotourism trip has a strong positive impact on the ecotourism purchase intention of the unfamiliar market. It is likely that considering these three perceived value factors the unfamiliar market will purchase ecotourism trips. Furthermore, empirical results of this study suggest that Conditional value has the strongest positive influence on ecotourism purchase intention followed by emotional value and Epistemic Value.

Another major conclusion from this study is partial mediation of destination image between the Perceived Ecotourism Valueand ecotourism purchase intention. The findings of the study are useful for formulating sustainable tourism policies and designing marketing strategies for ecotourism. The findings of the study are helpful for marketers to formulate awareness strategy regarding ecotourism to create destination image. The findings can also be used to formulate promotional strategy based on the three components (Conditional, Emotional, and Epistemic Value) to motivate the unfamiliar market for participation in the ecotourism trips. The study also makes substantial contribution in the body of knowledge by bringing forth the value perception factors considered by the unfamiliar market and the role of destination image in the decision making for ecotourism.

\section{References}

Adeleke, B. O. (2015). Assessment of residents' attitude towards ecotourism in KwaZulu-Natal protected areas. International Journal of Culture, Tourism, and Hospitality Research, 9(3), 316-328. 
Aratuo, D. N., \& Etienne, X. L. (2019). Industry level analysis of tourism-economic growth in the United States. Tourism Management, 70(September 2018), 333340 .

Amaro, S., Abrantes, J. L., \& Seabra, C. (2015). Comparing cb-sem and plssem results: An empirical example.

Akroush, M. N., Jraisat, L. E., Kurdieh, D. J., AL-Faouri, R. N., \& Qatu, L. T. (2016).

Tourism service quality and destination loyalty - the mediating role of destination image from international tourists' perspectives. Tourism Review, $71(1), 18-44$.

Ajzen, I. (1991). The theory of planned behavior. Organizational behavior and human decision processes, 50(2), 179-211.

Atieno, L., \& Njoroge, J. M. (2018). The ecotourism metaphor and environmental sustainability in Kenya. Tourism and Hospitality Research, 18(1), 49-60.

Bryman, A., \& Bell, E. (2011). Business Research Methods (3rd edition). Oxford University Press.

Chew, E. Y. T., \& Jahari, S. A. (2014). Destination image as a mediator between perceived risks and revisit intention: A case of post-disaster Japan. Tourism Management, 40, 382-393.

Chaminuka, P., Groeneveld, R. A., Selomane, A. O., \& Van Ierland, E. C. (2012). Tourist preferences for ecotourism in rural communities adjacent to Kruger National Park: A choice experiment approach. Tourism management, 33(1), $168-176$.

Chi, C. G. Q., \& Qu, H. (2008). Examining the structural relationships of destination image, tourist satisfaction and destination loyalty: An integrated approach. Tourism management, 29(4), 624-636.

Chiu, Y. T. H., Lee, W. I., \& Chen, T. H. (2014). Environmentally responsible behavior in ecotourism: Exploring the role of destination image and value perception. Asia Pacific Journal of Tourism Research, 19(8), 876-889.

Cohen, S., O'Leary, K. D., Foran, H. M., \& Kliem, S. (2014). Mechanisms of change in brief couple therapy for depression. Behavior therapy, 45(3), 402-417.

De Leeuw, A., Valois, P., Ajzen, I., \& Schmidt, P. (2015). Using the theory of planned behavior to identify key beliefs underlying pro-environmental behavior in high-school students: Implications for educational interventions. Journal of Environmental Psychology, 42, 128-138.

Fandos, C., \& Flavia'n, C. (2006). Intrinsic and extrinsic quality attributes, loyalty and buying intention: an analysis for a PDO product. British Food Journal, 108(8), 646-662.

Fishbein, M., \& Ajzen, I. (1975). Belief, attitude, intention and behavior: An introduction to theory and research.

Fornell, C., and Larcker, D. F. (1981). Evaluating Structural Equation Models with Unobservable Variables and Measurement Error. Journal of Marketing Research (18:1), pp. 39-50. 
Gallarza, M. G., \& Saura, I. G. (2006). Value dimensions, perceived value, satisfaction and loyalty: an investigation of university students' travel behaviour. Tourism management, 27(3), 437-452.

Gunn, C.A. (1972), Vacationscape: Designing Tourist Regions, Bureau of Business Research, University of Texas, Austin, TX.

Hardy, A., Vorobjovas-Pinta, O., \& Eccleston, R. (2018). Enhancing knowledge transfer in tourism: An Elaboration Likelihood Model approach. Journal of Hospitality and Tourism Management, 37(September), 33-41.

Hosseinalizadeh, S., Jabbari, S., \& Haghlesan, M. (2018). Assessment of Ecotourism From the Perspective of the Sustainable Development Based on Swot Model (Case: Azerbaijan Region of Iran). European Journal of Sustainable Development, 7(1), 163-174.

Huang, Y. C., \& Liu, C. H. S. (2017). Moderating and mediating roles of environmental concern and ecotourism experience for revisit intention. International Journal of Contemporary Hospitality Management, 29(7), 18541872.

Huang, Y. C., \& Liu, C. H. S. (2017). Moderating and mediating roles of environmental concern and ecotourism experience for revisit intention. International Journal of Contemporary Hospitality Management, 29(7), 1854-1872.

Hultman, M., Kazeminia, A., \& Ghasemi, V. (2015). Intention to visit and willingness to pay premium for ecotourism: The impact of attitude, materialism, and motivation. Journal of Business Research, 68(9), 1854-1861.

Jamrozy, U., \& Lawonk, K. (2017). The multiple dimensions of consumption values in ecotourism. International Journal of Culture, Tourism, and Hospitality Research, 11(1), 18-34.

Jamal, S. A., Othman, N. A., \& Muhammad, N. M. N. (2011). Tourist perceived value in a community-based homestay visit: An investigation into the functional and experiential aspect of value. Journal of Vacation Marketing, 17(1), 5-15.

Kim, J. H., \& Kim, Y. J. (2018). A research on recognition and demand of urban residents about introduction of mountain ecotourism. Forest Science and Technology, 14(2), 76-83.

Li, M., Cai, L. A., Lehto, X. Y., \& Huang, J. (2010). A missing link in understanding revisit intention-The role of motivation and image. Journal of Travel \& Tourism Marketing, 27(4), 335-348.

Lin, C. H., Sher, P. J., \& Shih, H. Y. (2005). Past progress and future directions in conceptualizing customer perceived value. International Journal of Service Industry Management, 16(4), 318-336.

Liu, J., Qu, H., Huang, D., Chen, G., Yue, X., Zhao, X., \& Liang, Z. (2014). The role of social capital in encouraging residents' pro-environmental behaviors in community-based ecotourism. Tourism Management, 41, 190-201.

Lee, T. H., \& Jan, F. H. (2018). Ecotourism Behavior of Nature-Based Tourists: An Integrative Framework. Journal of Travel Research, 57(6), 792-810. 
McDougall, G. H., \& Levesque, T. (2000). Customer satisfaction with services: putting perceived value into the equation. Journal of services marketing, 14(5), 392-410.

Memon, A. H., \& Rahman, I. A. (2014). SEM-PLS Analysis of Inhibiting Factors of Cost Performance for Large Construction Projects in Malaysia: Perspective of Clients and Consultants. The Scientific World Journal, 2014, 1-9.

Neill, J. (2007). Qualitative versus quantitative research: Key points in a classic debate. URL: http://wilderdom. com/research/QualitativeVersusQuantitativeResearch. htm retrieved on, 10(05), 2010.

Pandža Bajs, I. (2015). Tourist perceived value, relationship to satisfaction, and behavioral intentions: The example of the Croatian tourist destination Dubrovnik. Journal of Travel Research, 54(1), 122-134.

Perera, P., \& Vlosky, R. (2013). How Previous Visits Shape Trip Quality, Perceived Value, Satisfaction, and Future Behavioral Intentions: The Case of Forest-Based Ecotourism in Sri Lanka. International Journal of Sport Management, Recreation \& Tourism, 11.

Pike, S. (2002). Destination image analysis - a review of 142 papers from 1973 to 2000. Tourism management, 23(5), 541-549.

Sanchez, J., Callarisa, L., Rodriguez, R. M., \& Moliner, M. A. (2006). Perceived value of the purchase of a tourism product. Tourism management, 27(3), 394409.

Sarah, P., \& Claire, P. (2013). Internal and External Factors That Influence The Ecotourist. School of Business and Engineering: Halmstad University.

Sekaran, U.,(2003). Research Methods For Business, A Skill Building Approach, John Willey \& Sons. Inc. New York.

Seitbattalovna Kenebayeva, A. (2014). A study of consumer preferences regarding agritourism in Kazakhstan: A comparative study between urban and rural area consumers. Worldwide Hospitality and Tourism Themes, 6(1), 27-39.

Seow, A. N., Choong, Y. O., Moorthy, K., \& Chan, L. M. (2017). Intention to visit Malaysia for medical tourism using the antecedents of Theory of Planned Behaviour: A predictive model. International Journal of Tourism Research, 19(3), 383-393.

Sheth, J. N., Newman, B. I., \& Gross, B. L. (1991). Why we buy what we buy: A theory of consumption values. Journal of business research, 22(2), 159-170.

Su, R., Bramwell, B., \& Whalley, P. A. (2018). Cultural political economy and urban heritage tourism. Annals of Tourism Research, 68(October 2016), 30-40. http://doi.org/10.1016/j.annals.2017.11.004

Song, Z., Su, X., \& Liaoning Li. (2013). The Indirect Effects of Destination Image on

Destination Loyalty Intention Through Tourist Satisfaction and Perceived Value:

The Bootstrap Approach. Journal of Travel and Tourism Marketing, 30(4), 386409.

Tao, C. H., Eagles, P. F., \& Smith, S. L. (2004). Profiling Taiwanese

ecotourists using a self-definition approach. Journal of sustainable 
tourism, 12(2), 149-168.

Teeroovengadum, V., Seetanah, B., \& Nunkoo, R. (2018). The Influence of Travelers' Satisfaction with Destination Tertiary Services on Loyalty. Tourism Analysis, 23(4), 567-570.

Thompson, B. S., Gillen, J., \& Friess, D. A. (2018). Challenging the principles of ecotourism: insights from entrepreneurs on environmental and economic sustainability in Langkawi, Malaysia. Journal of Sustainable Tourism, 26(2), 257-276.

Ting, D. H., \& Cheng, C. F. C. (2017). Developing pro-environmental behaviour: ecotourism fieldtrip and experiences. International Journal of Sustainability in Higher Education, 18(7), 1212-1229. http://doi.org/10.1108/IJSHE-03-20160052

Westbrook, R. A., \& Reilly, M. D. (1983). Value-percept disparity: an alternative to the disconfirmation of expectations theory of consumer satisfaction. ACR North American Advances.

Woodruff, R. B. (1997). Customer value: the next source for competitive advantage. Journal of the academy of marketing science, 25(2), 139.

World Tourism Organization. (2017). Annual report of the World Tourism Organization. Retrieved from www.e unwto.org/doi/book/10.18111/9789284419807

Zeithaml, V. A. (1988). Consumer perceptions of price, quality, and value: a meansend model and synthesis of evidence. The Journal of marketing, 2-22.

Ziadat, M. T. A. (2015). Applications of planned behavior theory (TPB) in Jordanian Tourism. International Journal of Marketing Studies, 7(3), 95. 